Swarthmore College

Works

1998

\title{
Fragments Of An Early Thirteenth-Century St. Peter Window From The Cathedral Of Rouen
}

Michael Watt Cothren

Swarthmore College, mcothre1@swarthmore.edu

Follow this and additional works at: https://works.swarthmore.edu/fac-art

Part of the Ancient, Medieval, Renaissance and Baroque Art and Architecture Commons Let us know how access to these works benefits you

\section{Recommended Citation}

Michael Watt Cothren. (1998). "Fragments Of An Early Thirteenth-Century St. Peter Window From The Cathedral Of Rouen". Gesta. Volume 37, Issue 2. 158-164. DOI: 10.2307/767255

https://works.swarthmore.edu/fac-art/4

This work is brought to you for free by Swarthmore College Libraries' Works. It has been accepted for inclusion in Art \& Art History Faculty Works by an authorized administrator of Works. For more information, please contact myworks@swarthmore.edu. 


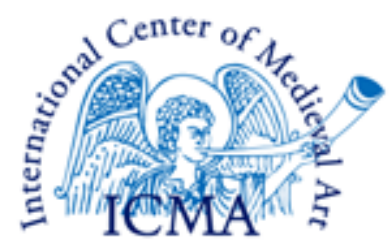

Fragments of an Early Thirteenth-Century St. Peter Window from the Cathedral of Rouen

Author(s): Michael W. Cothren

Source: Gesta, Vol. 37, No. 2, Essays on Stained Glass in Memory of Jane Hayward (19181994) (1998), pp. 158-164

Published by: The University of Chicago Press on behalf of the International Center of Medieval Art

Stable URL: http://www.jstor.org/stable/767255

Accessed: 27-03-2017 15:18 UTC

\section{REFERENCES}

Linked references are available on JSTOR for this article:

http://www.jstor.org/stable/767255?seq=1\&cid=pdf-reference\#references_tab_contents You may need to log in to JSTOR to access the linked references.

JSTOR is a not-for-profit service that helps scholars, researchers, and students discover, use, and build upon a wide range of content in a trusted digital archive. We use information technology and tools to increase productivity and facilitate new forms of scholarship. For more information about JSTOR, please contact support@jstor.org.

Your use of the JSTOR archive indicates your acceptance of the Terms \& Conditions of Use, available at http://about.jstor.org/terms

International Center of Medieval Art, The University of Chicago Press are collaborating with JSTOR to digitize, preserve and extend access to Gesta 


\title{
Fragments of an Early Thirteenth-Century St. Peter Window from the Cathedral of Rouen
}

\author{
MICHAEL W. COTHREN \\ Swarthmore College
}

\begin{abstract}
This article introduces three fragments from a stainedglass cycle of the life of St. Peter, once part of the nave aisle glazing of the cathedral of Rouen. Although the evidence they offer is diminished by their partial preservation, when these panels are associated with a previously recognized panel depicting St. Peter in the Glencairn Museum, a narrative cycle can be documented and firmer conclusions can be drawn concerning stylistic relationships among the "Belles Verrières" of the Rouen nave aisle. The examination of these fragments from technical and physical-as well as stylistic-standpoints confirms an assessment of the early thirteenth-century stainedglass workshop at the cathedral as a collective enterprise which united the work of several distinguishable artists.
\end{abstract}

The famous "Belles Verrières" installed in two north nave chapels of the cathedral of Rouen contain some of the most important paintings to have survived from the beginning of the thirteenth century. ${ }^{1}$ The stained-glass panels which comprise these windows were originally produced for the nave aisle openings during a reconstruction campaign at Rouen necessitated by a devastating fire in $1200 .{ }^{2}$ In the 1270 s, liturgical demands called for the construction of additional chapels between the buttresses along both sides of the nave, and the early thirteenth-century stained glass was removed, reworked, and reinstalled in the stylish, narrow lancets of the Rayonnant architectural additions. Although truncated, jumbled, and rearranged with no apparent regard for iconographic coherence, the early thirteenth-century scenes in these two "Belles Verrières" have provided modern scholars with sufficient evidence to identify at least seven windows (or subject matter groups) from the original glazing program $^{3}$ and to divide them stylistically among several artists or workshops. ${ }^{4}$

These north aisle "Belles Verrières" tell only part of the story. During the first half of the nineteenth century, they were complemented by two comparable ensembles, installed across the nave in south aisle chapels. In studies published in 1823 and 1832, Eustache Langlois documented these windows in the fifth and sixth openings from the west, ${ }^{5}$ and notes made on his own plan of the cathedral not only confirmed their location but also recorded an inscription on one panel. ${ }^{6}$ By the middle of the nineteenth century, however, the panels recorded by Langlois had already been removed. They were not mentioned by François de Guilhermy in $1856,{ }^{7}$ and in 1857 Ferdinand de Lasteyrie already noted their disappearance. ${ }^{8}$ Within a few decades the openings which held them had been filled with neo-Gothic pastiche (subsequently destroyed during the bombardments of 1944), and the displaced medieval panels secured in storage on the second floor of the northwest Tour Saint-Romain.

It was Jean Lafond who reconstructed the fascinating story of how and why the early thirteenth-century panels were dismounted from the south nave openings soon after Langlois documented them, as well as how and when some left Rouen and traveled through the art market to American collections. ${ }^{9}$ In 1911, granted a military leave to travel to Rouen and to inventory for officials of the Monuments Historiques the stained glass in storage at the cathedral, Lafond discovered that "s'y trouvaient entassés dans le plus grand désordre." Many panels-including the famous American Seven Sleepers panels once in the Henry Lawrence collection ${ }^{10}$ - had already been removed and sold, but of the early thirteenth-century glass displaced from the south nave windows, there still remained fifteen narrative scenes, as well as eleven ornamental fragments and twenty-nine border sections. ${ }^{11}$ Although Lafond made sure that these remaining panels were properly and securely stored, when he returned to the "dépôt" in 1931 to choose examples for an exhibition, ${ }^{12}$ he found little stained glass. The storage crates were filled primarily with stones, presumably an attempt to lend weight to the largely emptied containers and to disguise the removal of the stained glass. Lafond discovered that some of the "missing" sixteenth-century glass had been carelessly reused as stopgaps to fill holes in the cathedral glazing, ${ }^{13}$ but many panels-interestingly enough, in large part those identified in his inventory as the most important or best preserved - had been sneaked from storage and sold. Some have subsequently been identified in private collections and public museums. ${ }^{14}$ Included among the missing were two early thirteenth-century scenes from the legend of St. Peter. Their rediscovery and their integration into the study of the earliest stained glass of Rouen Cathedral are the subjects of this study.

\section{Surviving fragments of the St. Peter window}

Since Langlois did not specify the subject matter of the panels in the south nave "Belles Verrières," 15 Jean Lafond's 1911 inventory of removed and stored glass provides the first documentation of the existence of a St. Peter cycle among the early thirteenth-century nave aisle windows of the cathedral. ${ }^{16}$ He catalogued two panels: one composed of "fragments irréguliers" and portraying "St. Pierre et St. Paul?"; 


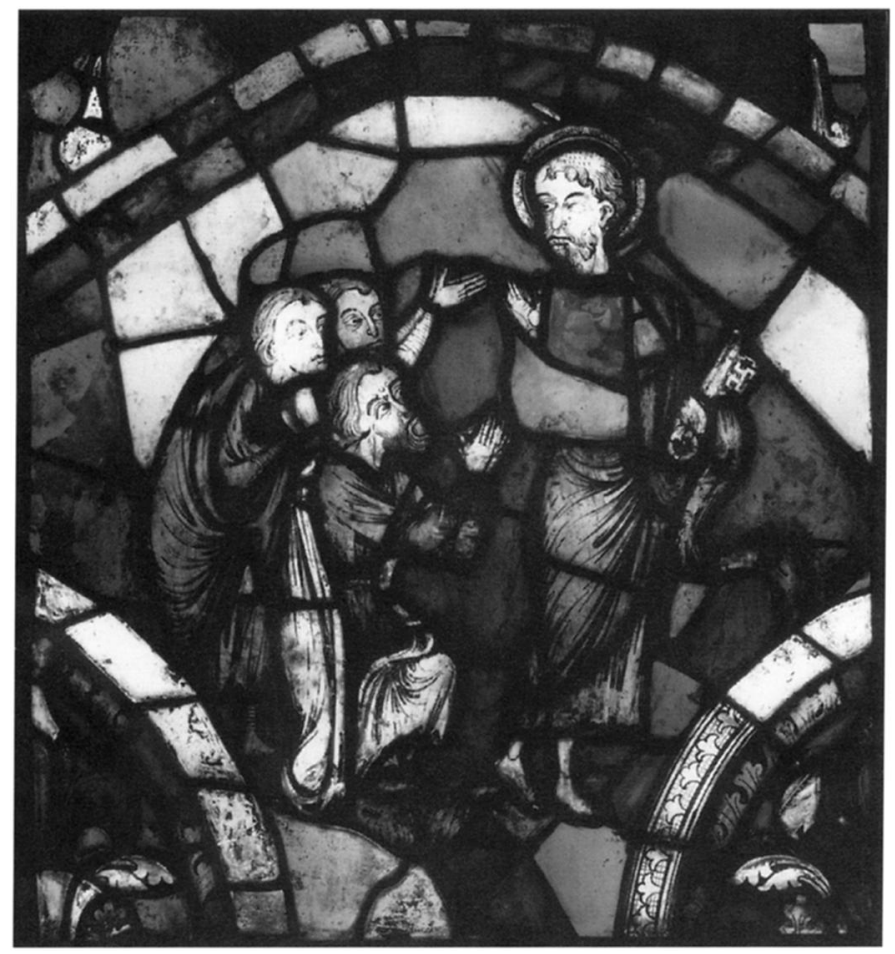

FIGURE 1. St. Peter turning to Address a Group of Followers, from the nave aisle windows of the cathedral, Rouen, now Bryn Athyn, PA, Glencairn Museum (photo: Metropolitan Museum of Art).

the other showing "St. Pierre s'adressant à plusieurs personnages agenouillés." His own published account of his return to the storage "dépôt" in 1931 indicates that both panels had disappeared between 1911 and 1931, except for "une demifigure du Prince des Apôtres." ${ }^{17}$ As I will attempt to demonstrate in the inventory that follows, ${ }^{18}$ one of these panels crossed the Atlantic to become part of the collection of Raymond Pitcairn. The other seems to have remained in Rouen, but in such deplorable condition that Lafond's failure to recognize it is hardly surprising. To these two I will add a third, also presumably included among the more ambiguously described panels in Lafond's 1911 list. The isolated torso of St. Peter, which he did find in 1931, may have been part of it originally. These meager, beleaguered, but extraordinary fragments will provide the basis for some concluding speculations on style, iconography, and the relation of this window to its companions in the early thirteenth-century nave aisle glazing.

\section{ST. PETER TURNING TO ADDRESS A GROUP OF} FOLLOWERS (Fig. 1 and Color Plate 2)

Rectangular panel, $75 \times 69 \mathrm{~cm}$

Bryn Athyn, PA, The Glencairn Museum (Raymond Pitcairn Collection), 03.SG.242.

It was Jane Hayward who first presented this panel as part of the important exhibition of highlights of the Raymond

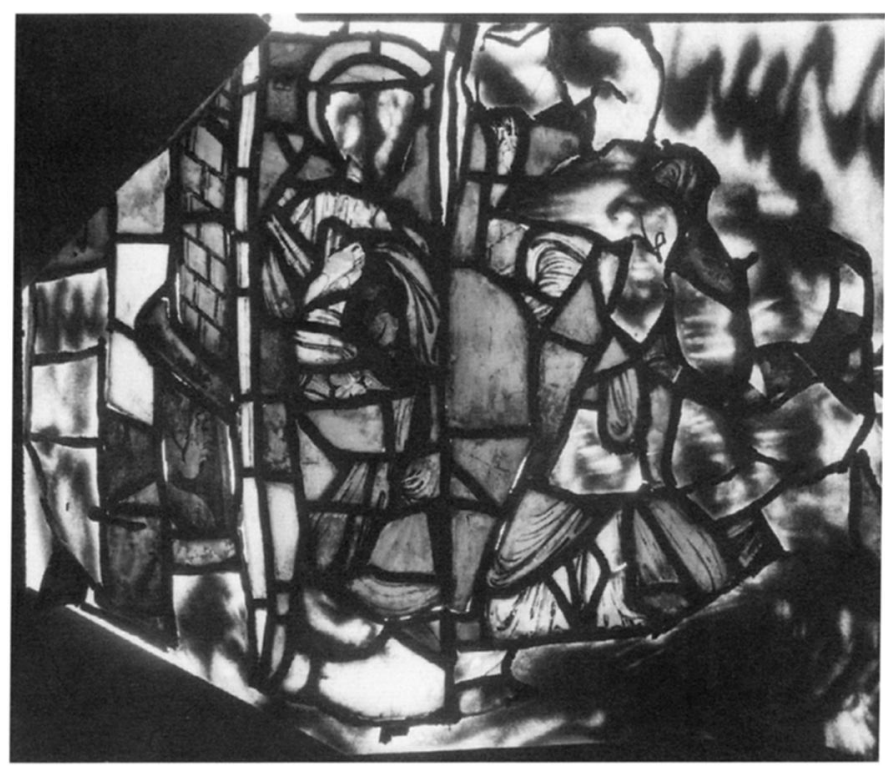

FIGURE 2. Rouen, cathedral of Notre Dame, fragment of a panel portraying St. Peter and a saintly companion, originally from a nave aisle window, now in a modern setting in the north choir chapel of SS. Peter and Paul (photo: Archives photographiques).

Pitcairn Collection in $1982 .{ }^{19}$ It can be identified with a scene already documented in Lafond's 1911 inventory as " $\mathrm{N}^{\circ} 2-$ Vitrail de St. Pierre. St. Pierre s'adressant à plusieurs personnages agenouillés devant lui. Magnifique panneau presque complet. $75 \times 70$." Although still roughly the same size, the panel seems to have undergone a major transformation during its journey through the art market. Whereas the figural core is fairly well preserved (replacements in the torso of St. Peter are the most prominent restorations), the ornamental surround in all four corners is completely modern. We do not know from whom Raymond Pitcairn purchased this panel, but his collection was formed for the most part during the years between 1911 and 1931, the interval during which it disappeared from Rouen.

\section{A FIGURE ADVANCING FROM THE LEFT TO EN- COUNTER ST. PETER STANDING IN OR NEAR A DOORWAY (Fig. 2)}

Irregular remnant of a rectangular panel; pre-restoration dimensions roughly $75 \times 65 \mathrm{~cm}$

Rouen, Cathedral of Notre Dame, north choir chapel of SS. Peter and Paul (nVIII [13], 6th panel from the bottom).

This fragmentary panel was one of eight chosen from the storage dépôt to be incorporated into a largely modern "reliquary" window created in 1980 by Sylvie Gaudin and installed at Rouen in the northern radiating chapel. Lafond had identified it as part of the Seven Sleepers series ${ }^{20}$ (from which the other seven panels in Gaudin's window were also 


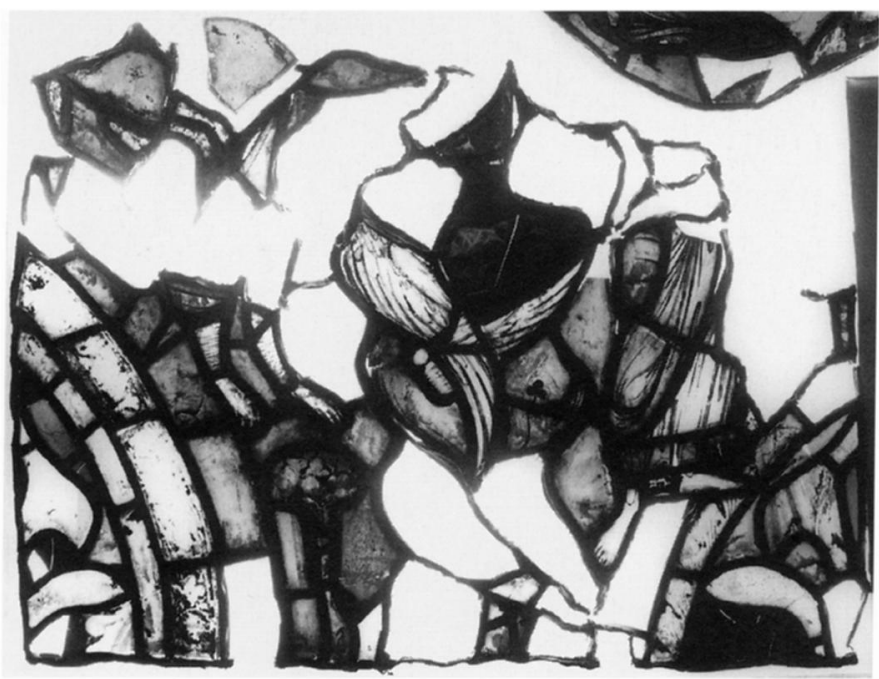

FIGURE 3. Fragmentary panel portraying the Fall of Simon Magus, originally from a nave aisle window of the cathedral, Rouen, presently Paris, Atelier Gaudin (photo: courtesy of the late Catherine Brisac).

drawn), but several factors argue for its association with the St. Peter window. Tucked under the right arm of the left figure are the shafts of a pair of keys with the characteristic double-line decoration familiar from other figures of St. Peter in this series (cf. Nos. 1 and 4). The delineation of drapery, and especially the spidery mannerism of hand gestures associate this panel stylistically with others in the St. Peter group. In fact, this could be the panel cited in Lafond's 1911 inventory as " $\mathrm{N}^{\circ} 1-$ Vitrail de St. Pierre. Fragments irréguliers, $70 \times 70$. St. Pierre et St. Paul?"21

\section{THE FALL OF SIMON MAGUS (Fig. 3)}

Irregular remnant of a rectangular panel, roughly $75 \times 52 \mathrm{~cm}$ Paris, Atelier Gaudin (in storage for the Ministère de la Culture).

This seems to represent the lower portion of a once-larger panel, now riddled with losses and sprinkled with stopgaps. Its iconographic identification is based on a recognition of the descending crisscrossed wings and the outstretched arms of the falling magician, which parallel the steep curve of the ornamental bands of the left corner; presumably St. Peter stands with conspicuously upright posture to the right. Enough remains here to demonstrate a stylistic affiliation with other St. Peter fragments, and despite the loss of the recognizable face and attribute of the protagonist, the iconography is distinctively appropriate for a window of this theme. Most interesting is the preservation of enough original ornament in the lower corners to authenticate the general composition, color distribution, and some painted articulation of the modern design at the bottom of the Glencairn panel (No. 1), which is almost identical in width.

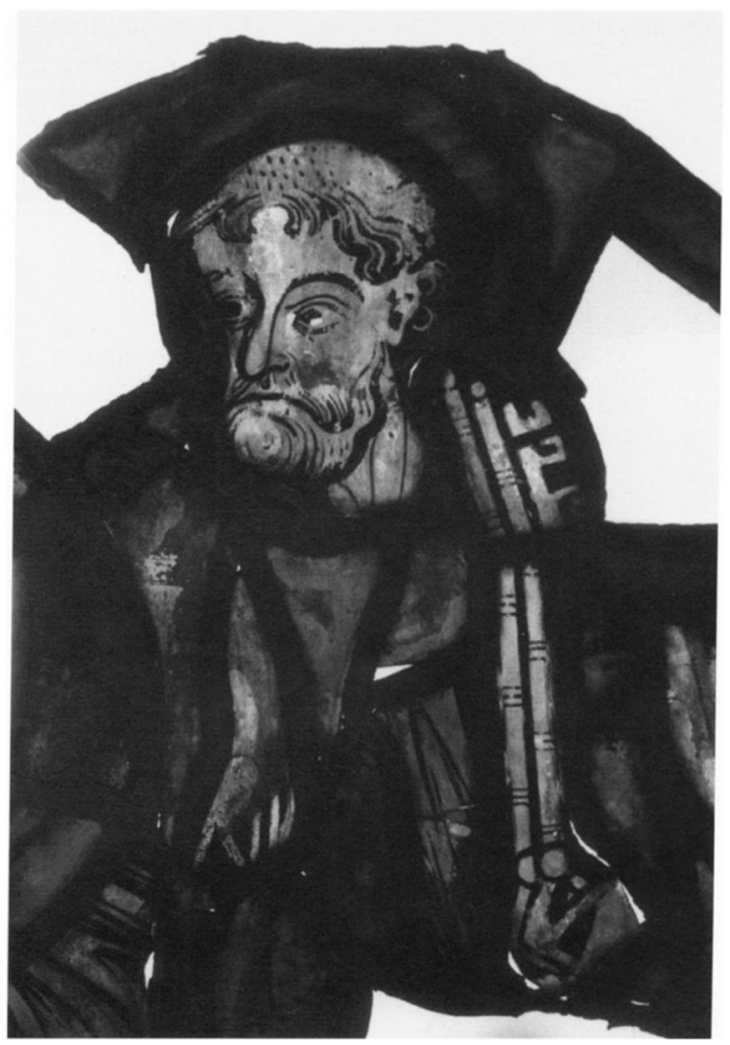

FIGURE 4. Fragmentary figure of St. Peter, originally from a nave aisle window of the cathedral, Rouen, presently Paris, Atelier Gaudin (photo: author).

\section{HEAD AND FRAGMENTARY TORSO OF ST. PETER} (Fig. 4)

A jumble of fragments surrounding a figural core (?), roughly $23 \times 28 \mathrm{~cm}$

Paris, Atelier Gaudin (in storage for the Ministère de la Culture).

This is probably the "demi-figure du Prince des Apôtres," the only remnant of the St. Peter window found by Lafond when he returned to the storage dépôt in $1931,{ }^{22}$ it was exhibited that year in Rouen. ${ }^{23}$ In both scale and painting style, the head of this Peter is virtually identical to its counterpart at Glencairn (No. 1 above). It is possible that this assemblage once completed the half-figure-presumably of Peterstanding at the right of the previous partial panel (No. 3), but the poor condition of both fragments precludes any definite conclusion. ${ }^{24}$

\section{Iconography}

The few and fragmentary remains from this ensemble can support only a limited iconographic assessment of the window which originally contained them. Indeed, only the appearance of the protagonist's attributive keys allows three 
of the inventoried panels (Nos. 1-2,4) to be identified with a visual narrative of Peter's life, ${ }^{25}$ and since pairings of the lives of Peter and Paul within a single opening were popular in cathedral glazings at this time, ${ }^{26}$ the possibility cannot be eliminated that these panels were originally part of a window which interwove these two apostolic lives. The two more generic scenes of St. Peter addressing followers (No. 1) and confronting from a doorway an approaching saintly colleague (No. 2) could be associated with numerous episodes from the textual tradition of St. Peter's life. Since they are so general, it is easy to find close, if not exact, parallels in other windows from the first half of the thirteenth century. ${ }^{27}$ The fragmentary depiction of the fall of Simon Magus (No. 3), however, is more distinctive, and it can be associated authoritatively with a single, focused hagiographic episode. An encounter between apostle and magician is documented in the New Testament (Acts 8:9-24), but the popular story of Simon's failed attempt at flight which is portrayed here derives from the apocryphal account in the Acts of Peter. ${ }^{28}$ The inclusion of this climactic narrative event is common in thirteenth-century extended visual narratives of Peter's life. It appears in stained-glass window cycles at Angers (choir clerestory), Auxerre (ambulatory), Chartres (both the ambulatory of the cathedral and the nave of Saint-Père), Le Mans (two separate ambulatory clerestory windows), Tours (hemicycle clerestory), and Troyes (chapel).

\section{Style}

Similarly difficult to assess is the overall design of the window which originally contained the St. Peter panels. Already in the later thirteenth century they had undergone major modifications to accommodate a reinstallation; modern neglect and misuse have left only ragged fragments and greatly diminished evidence of compartment shape and ornamental setting. What seems to be the most extensive information in the lower corners of the Glencairn panel is actually a composite of entirely modern glass. ${ }^{29}$ Remaining glass at the bottom of the tattered scene of the Fall of Simon Magus, however, allows us to presume that the curving fillets which enclose half palmettes at the lower corners of the Glencairn panel are modern copies of a thirteenth-century design; space remains around the panel now installed at Rouen (No. 2) to accommodate comparable ornamental fill. Presumably such foliate corner motifs were connected with symmetrical counterparts in panels beneath and beside them to create the ornamental binding or background of the window. If ornamental corners were cut into both the top and bottom of the complete panels, several roughly contemporary ensembles from Bourges provide compelling design parallels for potential arrangements, ${ }^{30}$ but choosing among them, or choosing to be limited by them, would be only conjecture. There is insufficient evidence to hazard a reconstruction of the original window design.

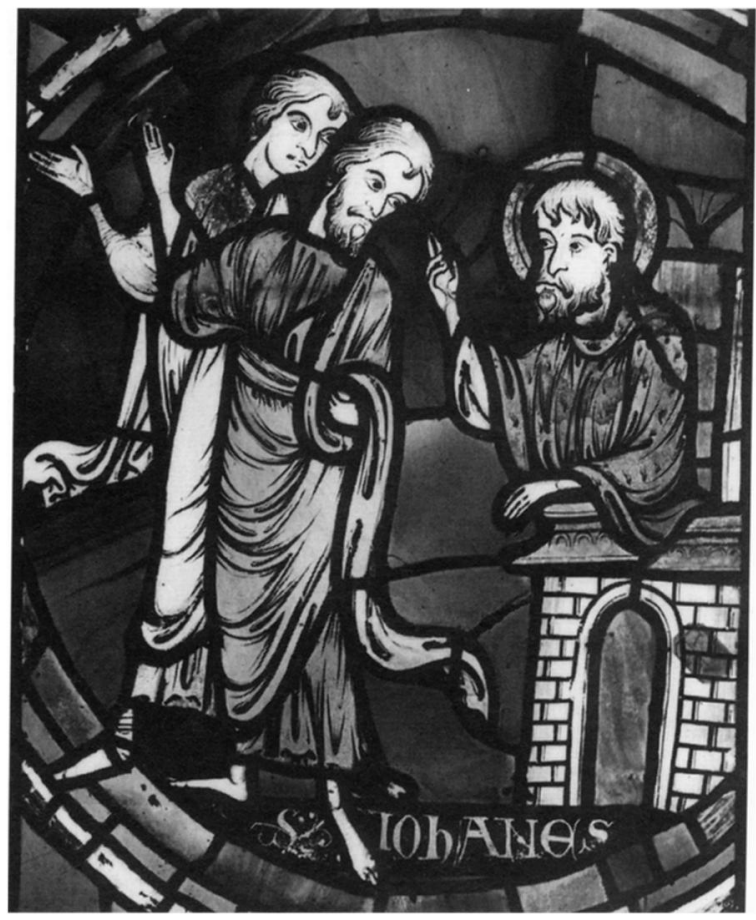

FIGURE 5. Rouen, cathedral of Notre Dame, scene from the life of John the Baptist, now in the "Belles Verrières" of the chapel of Saint-Jean-de-la-nef (photo: Archives photographiques).

On the more detailed level of physical composition and figural style, it is possible to come to firmer conclusions, since the fragmentary remains of the St. Peter window are consistent in general character and appearance with other surviving panels from the early thirteenth-century glazing of the Rouen nave aisle. The materials used and the way they were deployed find parallels, for example, in surviving panels from the window of the Seven Sleepers of Ephesus. The glass in both series is thick, undulating, and permeated with an abundance of small bubbles which occasionally surfaced in manufacture to form sprinklings of pimple-like protrusions, especially noticeable here since much of the glass is exceptionally strong and free in broad areas from any surface corrosion. Red, rose-purple, blue, and the tones used for skin are striated, whereas greens and whites are generally clear and homogeneous. Since the reddish paint articulating this glass did not adhere firmly in firing, there is considerable loss of painted line throughout. The lines themselves are streaky in appearance. Several irregular strokes were often employed in the creation of a single line or wash, a technique which leads to a build-up of paint in relief, noticeable only when the panels are examined in raking light.

The artists who painted the early thirteenth-century Rouen nave aisle windows shared not only materials, but systems for the delineation of drapery and faces. This can be seen by comparing a panel from the John the Baptist window (Fig. 5), 
attributable to the same artist(s) who created the Seven Sleepers window, ${ }^{31}$ with the Glencairn panel from the St. Peter series. The heads of the auditors in both compositions are capped with wig-like coiffures, featuring overlapping waves of heavy curls, usually punctuated by a curving forelock. Two-part beards are concentrated heavily and pendulously on the chin but prepared with more delicate locks above on the jaw. Eyes are delineated primarily by two lines pinched but opened at the outside. Pupils are large and tucked into the corner of the eye; noses are long, often hooked. Drapery is either pulled in sweeps against the form of the body or allowed to tumble amply over solid shapes. Where there is empty space to be filled, however, the ends of mantles occasionally curve out to fill the void. When comparison is extended from these two panels to all those that remain from the "Belles Verrières," many shared systems of painting can be documented in figures and ornament, suggesting that the earliest panels in the "Belles Verrières" are united as products of one, possibly local style. This shared tradition of glass painting, however, seems to have supported several individualized inflections.

In comparison with panels from the windows of the Seven Sleepers and of John the Baptist, ${ }^{32}$ the painting of the St. Peter fragments seems less assured or more rigid. The fragments are also characterized by the distinctively bulbous contours of individual pieces of glass, not only those on which the figures have been painted, but even those united to comprise the negative space of the unpainted blue ground (noticeable in both Figs. 1 and 3). The broader, languidly curving cut lines which characterize the work of the Seven Sleepers and John the Baptist painter(s) (Fig. 5) provide a sharp contrast with these more swelling outlines of the St. Peter painter(s) (esp. Fig. 1); these elastic shapes are reinforced by the painting of tear-shaped mounds of falling drapery (foreground kneeler in Fig. 1) and pinched or elliptically stretched fold patterns (mantle of St. Peter in Figs. 1 and 3). All of these characteristics confer malleability in the delineation of form. In general, drapery articulation is standardized, often dry, privileging surface pattern over the fictitious evocation of formal solidity, a specialty of the other painter(s). In comparison with the graceful monumentality of the figures of the Seven Sleepers and John the Baptist panels, St. Peter's head (Fig. 1) seems unusually large in relation to his short, stocky body and diminutive feet and hands. The mannered figures of this series employ awkwardly jutting or retracted gestures and dazed facial expressions. Their interaction lacks the tense, psychological narrative and monumental decorum that characterize figural groupings in the Seven Sleepers and John the Baptist series, even when very similar line systems are employed for folds and faces.

\section{Conclusions}

The remaining evidence is slight, but the examination of these newly introduced fragments expands in several signifi- cant ways our understanding of the early thirteenth-century nave aisle glazing at Rouen. An additional narrative cycle can be added to its hagiographic anthology, although it is impossible to be certain whether the life of St. Peter occupied an entire lancet or shared this position with events in the life of St. Paul, as was the case elsewhere. A new painter (perhaps a group of painters) with a distinctive stylistic personality can be documented within the overarching (local?) style which characterizes several ensembles within the "Belles Verrières." ${ }^{33}$ What may be most interesting is the confirmation provided by the study of this glass of the notion that several master painters with distinctive though related styles of painting may have worked cooperatively within a large workshop at the cathedral of Rouen when the new nave aisles were under construction. ${ }^{34}$ This assessment, though implied by stylistic relationships and distinctions, relies heavily on the consistency of the materials with which the windows were made. Since the iconography of the Seven Sleepers window allows it to be dated with rare precision between 1200 and $1203,{ }^{35}$ it is reasonable to date the other windows related to it-and thus the activity of this large collective workshop-within the first decade of the thirteenth century, including the St. Peter series surveyed here.

\section{NOTES}

1. For the "Belles Verrières," see principally G. Ritter, Les vitraux de la cathédrale de Rouen, XIIIe, XIVe, XVe et XVIe siècles (Cognac, 1926), 7-8, 37-42, Pls. I-VIII; J. Lafond, "La verrière des Sept Dormants d'Ephèse et l'ancienne vitrerie de la cathédrale de Rouen," in The Year 1200: A Symposium (New York, 1975), 399-416; F. Perrot, Le vitrail à Rouen (Connaître Rouen, II, 7) (Rouen, 1972), 11-13; L. Grodecki and C. Brisac, Le vitrail gothique au XIIIe siècle (Fribourg, 1984), 4849, 257; and M. W. Cothren, "The Seven Sleepers and the Seven Kneelers: Prolegomena to a Study of the 'Belles Verrières' of the Cathedral of Rouen," Gesta, XXV (1986), 203-226, esp. 219, n. 1, which contains a fuller bibliography.

2. The fire of April 1200 is documented in the Chronicon Rotomagense, published in M. Allinne and A. Loisel, La cathédrale de Rouen avant l'incendie de 1200. La tour Saint-Romain (Rouen, 1904), 66. Although the text is explicit-“combusta est tota ecclesia Rothomagensis cum omnibus campanis, libris et ornamentis Ecclesiae et maxima pars civitatis et multae Ecclesiae"-there is some controversy concerning the relationship between the fire and building chronology at the cathedral (see Cothren, "Seven Sleepers," 221-222, n. 41). Post-fire construction was, however, clearly responsible for the openings which once held the nave aisle windows.

3. Ritter (Les vitraux, 7-8, 37-41) and Lafond ("La verrière des Sept Dormants d'Ephèse," 408, n. 12) identified scenes from the lives of SS. John the Baptist, Severus, Catherine, Stephen, and Nicholas, as well as scenes from the life of Job and perhaps fragments of a window dedicated to the Apostles. I have since identified a scene from the life of John the Evangelist: Cothren, "Seven Sleepers," 213-216. This note on the St. Peter window is drawn from a larger study of the nave aisle glazing now in progress, which will seek to bring the iconography of the ensemble into sharper focus. 
4. For the styles represented in the "Belles Verrières," see principally Ritter, Les vitraux, 7-8; J. Hayward in New York, The Metropolitan Museum of Art, Radiance and Reflection. Medieval Art from the Raymond Pitcairn Collection (New York, 1982), 152, 154-155; Grodecki and Brisac, Le vitrail gothique, 48-49, 257; and Cothren, "Seven Sleepers."

5. E. H. Langlois, Mémoire sur la peinture sur verre et sur quelques vitraux remarquables des églises de Rouen (Rouen, 1823), 12; idem, Essai historique et descriptif sur la peinture sur verre ancienne et moderne, et sur les vitraux les plus remarquables de quelques monuments français et étrangers (Rouen, 1832), 29-32. In describing the "Belles Verrières," the 1832 book repeats exactly what had been published in 1823 .

6. It was this inscription which allowed Jean Lafond (who once possessed Langlois's plan) to associate an extensive series of extant panels portraying scenes from the legend of the Seven Sleepers of Ephesus with one of these south aisle windows. See Lafond, "La verrière des Sept Dormants d'Ephèse."

7. In notes made during visits to Rouen in 1856 and 1864 (Paris, Bibliothèque Nationale, nouv. acq. fr. MS 6107, fols. 139-140v), Guilhermy recorded no thirteenth-century glass in the south nave chapels comparable to that which he described in two north nave chapels-the "Belles Verrières" which remain in that location today.

8. F. de Lasteyrie, Histoire de la peinture sur verre d'après ses monuments en France, I (Paris, 1857), 182-183.

9. Lafond, "La verrière des Sept Dormants d'Ephèse," 399-401.

10. These four panels were sold in 1921 (American Art Association, Sale Catalogue, Collection of a Well-Known Connoisseur, A Noteworthy Gathering of Gothic and Other Ancient Art Collected by the Late Mr. Henry C. Lawrence of New York [New York, 28 January 1921], 375 and 377). They are now divided between the Worcester Art Museum and the Glencairn Museum. A note in the files at the Glencairn Museum indicates that Lawrence had acquired the panels from the Parisian dealer Bacri. See Cothren, "Seven Sleepers," esp. 225. For other panels which must have left the "dépôt" before 1911, see also Lafond, "La verrière des Sept Dormants d'Ephèse," 408, n. 16.

11. A considerable amount of glass dating from the fourteenth through sixteenth centuries had also been stored in the tower dépôt, notably a scene from the legend of St. Eustace, eight panels from a life of St. Catherine, and a window created in 1528 for the confraternity of Notre-Dame du Jardin by Engrand Le Prince, portraying the death, assumption, and coronation of the Virgin. Part of this precious ensemble, which disappeared from storage in Rouen between 1911 and 1931, has recently been identified by Michel Hérold in the Philadelphia Museum of Art: Rouen, Musée des Beaux-Arts, Vitraux retrouvés de SaintVincent de Rouen (Rouen, 1995), 49.

12. Six panels of thirteenth-century glass from Rouen were ultimately incorporated into this exhibition, including the torso of St. Peter to be discussed below. See F. Guey and J. Lafond, Catalogue de l'exposition d'art réligieux (Rouen, 1931), Nos. 308-313, pp. 103-104.

13. Visible in Ritter, Les vitraux, $\mathrm{Pl}$. XCV.

14. E.g., a scene from the Seven Sleepers window (illustrated in color on the cover of this issue of Gesta) once in the Raymond Pitcairn Collection and now in the Metropolitan Museum of Art (Cothren, "Seven Sleepers," 225, Appendix, No. 4); and the two panels now in the Philadelphia Museum of Art mentioned above in n. 11.

15. Langlois, Mémoire sur la peinture sur verre, 12. He was more specific when describing the north nave "Belles Verrières" (noting on p. 11 scenes from the lives of St. John the Baptist, St. Nicholas, and St. Sever), but turning to the early thirteenth-century panels in the south aisle, he characterized those in the fifth chapel simply as "quelques anciennes peintures" and those in the sixth chapel as "quelques faits de la vie d'un saint, accompagnés de plusieurs inscriptions, commençant par l'expression indicative Hic." The scenes with inscriptions presumably came from the Seven Sleepers window; perhaps the St. Peter panels were in the fifth chapel.

16. I am extremely grateful to Françoise Perrot, who in 1982 gave me a copy of Jean Lafond's unpublished inventory, dated 20 April 1911, and provided me with free access to Lafond's valuable notes on Rouen.

17. Lafond, “La verrière des Sept Dormants d'Ephèse," 401.

18. I first inventoried this glass in 1982-1983 during research which led to a report to the French Ministère de la Culture on fragments from Rouen, delivered on 15 February 1983: "A Preliminary Report on Fragments of Thirteenth-Century Stained Glass from the Original Nave Aisle Glazing of the Cathedral of Rouen now Divided Between a Choir Chapel at Rouen, the Gaudin Atelier in Paris, and the Storage Depot at the Chateau of Champs-sur-Marne." Copies of this report were also filed at The Cloisters and the Glencairn Museum.

19. Hayward, in Radiance and Reflection, 152-155.

20. Lafond, "La verrière des Sept Dormants d'Ephèse," 403, No. 3.

21. For another possible iconographic identification, see n. 27 below.

22. Lafond, "La verrière des Sept Dormants d'Ephèse," 401.

23. Guey and Lafond, Catalogue de l'exposition, No. 308, p. 103.

24. There are further fragments from the St. Peter window among the Rouen glass that was divided in 1982 between the Laboratoire des Monuments Historiques in the Chateau of Champs-sur-Marne and the Atelier Gaudin, but none is substantial enough to merit much attention in this brief study. Most notable are a leaded ensemble composed of two pieces of white drapery attached to a morsel of green glass (G11 in Cothren, "Preliminary Report") and a piece of brownish-purple (murrey) drapery ( $\mathrm{Cm} 12$ in Cothren, "Preliminary Report"). The identification of these shards with the St. Peter window is based on the style of cutting and the painted articulation, painting technique, and type of glass.

25. The life of St. Peter was a popular subject in thirteenth-century glazings. Windows - or partial windows-of this theme survive at Angers, Auxerre, Bourges, Chartres (the cathedral and Saint-Père), ClermontFerrand, Dijon, Le Mans, Rouen (ambulatory), Saint-Julien-du-Sault, Semur en Auxois, Tours, and Troyes. There are also notable twelfthcentury precursors at Lyon and Poitiers.

26. Thirteenth-century windows which combine episodes from the lives of Peter and Paul within a single opening appear at Auxerre, Bourges, Chartres, Rouen (ambulatory), and Troyes (clerestory). For the early history of the association of Peter and Paul in the visual arts, see R. Wilkins Sullivan, "Saints Peter and Paul: Some Ironic Aspects of their Imaging," Art History XVII (1994), 59-80.

27. One scene in the chapel windows at Troyes (sVIII, 37; illustrated in Grodecki and Brisac, Le vitrail gothique, 263) provides an especially intriguing parallel for No. 2. A figure of St. Peter walks away from an architectural tower on the left and encounters a standing and blessing figure of Christ who is approaching from the right. Since the figure on the right in the Rouen panel is of uncertain identity, we cannot know if that panel, like the one in Troyes, represented Peter's encounter with Christ during a hasty departure from Rome, the "Domine quo vadis" scene which is a prelude to Peter's martyrdom.

28. For the Acts of Peter, see E. Hennecke, New Testament Apocrypha, ed. W. Schneemelcher (Philadelphia, 1965), II, 259-322 (315-316 for the flight of Simon Magus). See also L. Réau, Iconographie de l'art chrétien III/3 (Paris, 1959), 1093-1095.

29. Unfortunately, this transformation seems to post-date 1911, when Jean Lafond described this panel as a "magnifique panneau presque complet." 
30. The designs of the St. Stephen, St. John and St. Cecilia windows at Bourges (which fill relatively narrow openings, like those in the Rouen nave aisle) are created by the accumulation and juxtaposition of paired panels of consistent design which includes ornamental corners that link with their counterparts in neighboring panels to provide binding continuity. If all panels were identical in design and the lower ornament in the panels surviving from Rouen (Nos. 1 and 3) was originally mirrored in the top corners, the St. Peter series could have been arranged in a fashion similar to these Bourges windows. It is also possible, however, that a central panel designed in this way could have been complemented laterally by semicircular compartments to create an arrangement more like the St. Mary Magdalene window at Bourges. See C. Cahier and A. Martin, Monographie de la cathédrale de Bourges (Paris, 1841-1844), II, Pls. XI A, XV B, XVI A, and XVI B.

31. Jean Lafond ("La verrière des Sept Dormants d'Ephèse," 399) credited Louis Grodecki with the observation that these two series were the work of the same artist, who was subsequently dubbed the John the Baptist Master.

32. Only one panel from this group could be illustrated here for comparison. For others, see, for the John the Baptist cycle: Ritter, Les vitraux, Pls. I-IV; and for the Seven Sleepers (in addition to the panel illustrated in color here on the cover): Cothren, "Seven Sleepers," and Lafond, "La verrière des Sept Dormants d'Ephèse."

33. In addition to the John the Baptist Master and the author(s) of the St. Peter fragments introduced here, a third artist or group of artists- distinctive but working within the same (local?) tradition-can be identified in a series of panels in the north nave "Belles Verrières" portraying scenes from the life of St. Severus of Avranches (and Ravenna?). Jane Hayward, in Radiance and Reflection, 154-155, associated the St. Peter panel in Glencairn with this St. Severus painter, but the similarities she cites indicate, I believe, that the artists of the St. Peter and St. Severus windows shared a stylistic tradition, not that the same artist executed both series, even if their work bears closer comparison than does the work of either with that of the John the Baptist Master. I will be returning to the question of style and authorship in the Rouen nave aisle glazing in the larger study cited above, n. 3.

34. I offered this suggestion in Cothren, "Seven Sleepers," 225, n. 90. I have discussed evidence for a comparable, if considerably earlier, workshop arrangement at Saint-Denis: M. W. Cothren, "Suger's Stained Glass Masters and their Workshop at Saint-Denis," in Paris Center of Artistic Enlightenment (Papers in Art History from The Pennsylvania State University, IV) (University Park, 1988), 47-75. For other instances and interpretations of collaboration in the production of thirteenth-century stained-glass windows, see C. Lautier, "Les peintres-verriers des bascôtés de la nef de Chartres au début du XIIIe siècle," BMon, CXLVIII (1990), 7-45; and M. P. Lillich, The Armor of Light: Stained Glass in Western France, 1250-1325 (Berkeley, 1994), 216-217, 309-310.

35. Cothren, "Seven Sleepers," 208-213. 